\title{
Nematode assemblages of some insular and continental lizard hosts of the genus Mabuya Fitzinger (Reptilia, Scincidae) along the eastern Brazilian coast
}

\author{
Carlos Frederico D. Rocha ${ }^{1,2}$ \& Davor Vrcibradic ${ }^{1}$
}

1 Setor de Ecologia, Instituto de Biologia, Universidade do Estado do Rio de Janeiro. Rua São Francisco Xavier 524, Maracanã, 20550-019 Rio de Janeiro, Rio de Janeiro, Brasil.

2 Corresponding author. E-mail: cfdrocha@uerj.br

\begin{abstract}
Nematode assemblages associated to three species of lizards of the genus Mabuya Fitzinger, 1826 [M. agilis (Raddi, 1823), M. caissara Rebouças-Spieker, 1974 and M. macrorhyncha Hoge, 1946] from three mainland sites and three island sites along the eastern Brazilian coast were analyzed. A total of six nematode species were recorded, with total nematode richness varying from one to four and overall nematode prevalences varying from $6.7 \%$ to $90.5 \%$ among host populations. Number of nematode species per host individual (including all hosts, infected and uninfected) varied among host populations from 0.07 to 1.05 , but most infected lizards in all six host populations harbored a single nematode species. Both insular and continental populations of Mabuya spp. exhibited generally poor nematode assemblages, and no clear tendency for insular host populations to have more depauperate nematode faunas and/or lower infection rates compared to mainland ones (or vice versa) was evident on the basis of the present data.
\end{abstract}

KEY WORDS. Infection rates, Mabuya, nematode parasites, species richness.

The nematode fauna associated to the digestive tract of terrestrial reptiles is usually considered to be relatively poor compared to those of other vertebrates (e.g. Ано 1990, Busн et al. 1990, POULIN \& MORAND 2000). Regarding reptiles in general, and lizards in particular, there have been few studies addressing comparisons of helminth faunas among congeneric and/ or conspecific lizard populations from different localities (e.g. Dobson et al. 1992, Dobson \& Pacala 1992, Biserkov \& Kostadinova 1998, Sharpilo et al. 2001, VRCibradic et al. 2002b). Among such studies, only the ones of Dobson et al. (1992) and Dobson \& PaCala (1992) dealt specifically with insular host populations. They have found that the helminth faunas associated to Anolis Daudin, 1802 lizards in the northern Lesser Antilles are depauperate compared to those of the larger Caribbean islands. This probably reflects the effect of isolation, with insular populations of both parasites and free-living organisms being more sensitive to stochastic effects (e.g. MacArThur \& WiLson 1963, 1967, Dobson et al. 1992, Rozenzweig 1995).

In South America, studies addressing ecological parameters of lizard helminth assemblages are still relatively scarce (considering the richness of the continent's lizard fauna), despite a number of recent contributions dealing with Brazilian taxa (van SLuys et al. 1994, 1997, Ribas et al. 1995, 1998a,b, RоснA 1995, VRCiBRAdic et al. 1999, 2000, 2001, 2002a,b, Rocha et al. 2003). However, insular host populations have not been examined during the above referred investigations. In the present study, the nematode faunas associated to insular populations of scincid lizards (Mabuya spp.) were analyzed and compared with those of the nearest mainland congeneric populations for which the authors have such data. The issue of whether there is a tendency for depauperation in nematode assemblages of insular hosts, compared to those of mainland congeners, was specifically addressed.

\section{MATERIAL AND METHODS}

\section{Host species}

Lizards of the genus Mabuya Fitzinger, 1826 are widespread along the coastal plains of southeastern and northeastern Brazil. Within the coastal strip stretching from southern Bahia to São Paulo, in particular, three species are known to occur, often in relatively high densities: Mabuya agilis (Raddi, 1823), M. caissara Rebouças-Spieker, 1974 and M. macrorhyncha Hoge, 1946. The former two species are very similar in habits and appearance (pers. obs.) and appear to be closely related (Rосна 2000). All three species are found both on the mainland and on islands along the eastern Brazilian shores (REBOUÇASSPIEKER 1974, ROCHA 2000).

\section{Study areas}

Lizards of the genus Mabuya were sampled in three islands along the Brazilian coast and in some continental coastal areas close to these islands: a) Ilha da Queimada Grande island 
(Mabuya macrorhyncha) (Itanhaém Municipality) and the continental area of Massaguassu beach (Mabuya caissara) in Caraguatatuba Municipality, both located in the coast of São Paulo State (Fig. 1); b) Praia do Sul, in Ilha Grande island (Mabuya agilis) (Angra dos Reis Municipality) and the continental area of the Grumari restinga in Rio de Janeiro Municipality (M. agilis and_M. macrorhyncha), both in Rio de Janeiro State; c) Sueste Island, in the Abrolhos Archipelago (Mabuya agilis) and a continental restinga area in Trancoso Municipality (Mabuya macrorhyncha), both in Bahia State (Fig. 1). Collections were mostly done from 1997 to 1999, except for the sample of Ilha Grande (collected in February 2001) and some animals from Grumari that were collected in 1995 and 1996. Except for Queimada Grande and Abrolhos, all sampled localities represent restinga habitats (restingas are coastal sandy habitats with xerophilous vegetation). Queimada Grande is covered mostly by tropical rainforest, whereas Sueste island is covered by herbaceous vegetation. Data on the helminth faunas of M. agilis from Grumari and of_M. macrorhyncha from Trancoso have already been published elsewhere (VRCIBRADIC et al. 2001, 2002a), whereas the remaining are original data.

\section{Methodology}

Lizards were euthanized with ether immediately upon collection and their snout-vent length (SVL) was measured with a digital caliper (to the nearest $0.1 \mathrm{~mm}$ ), before fixation in $10 \%$ formalin and preservation in $70 \%$ ethanol. In the laboratory, the digestive tract, body cavity, liver and lungs of each individual were examined under a stereomicroscope for the presence of helminths. Only lizards equal to or larger than $50 \mathrm{~mm} \mathrm{SVL}$ were considered, to avoid a possible effect of the proportion of juveniles per sample on infection rates, given that juveniles are likely to be less frequently infected than adults due to their shorter periods of exposure to potential parasites. All nematodes found were removed, cleared in phenol, and prepared as temporary slides for identification.

Mean number of nematode species per host (including all examined hosts, both infected and uninfected) was compared among samples of the six localities using one-way Analysis of Variance (ANOVA) coupled with a Tukey test for multiple comparisons.

Ecological/parasitological terminology used throughout the text follows Bush et al. (1997).

\section{RESULTS}

A total of six nematode species were found to parasitize the three skink species studied: Parapharyngodon sceleratus (Travassos, 1923) and P. largitor Alho \& Rodrigues, 1963 (Pharyngodonidae) - found in the gut, Physalopteroides venancioi (Lent, Freitas \& Proença, 1946) and Physaloptera sp. (Physalopteridae) - found in the stomach, Hexametra boddaertii (Baird, 1860) (Ascarididae) - found in the coelom and an indeterminate acuariid (Tab. I) - found in the stomach wall (encysted), stomach and gut. The latter three forms were found only as larvae. Infections by more than one nematode species were recorded in two individuals of $M$. macrorhyncha from Queimada Grande and two from Trancoso and in six M. agilis from Grumari and two from Abrolhos. The remaining infected lizards harbored nematodes of only one species.

Parameters of the helminth communities associated to

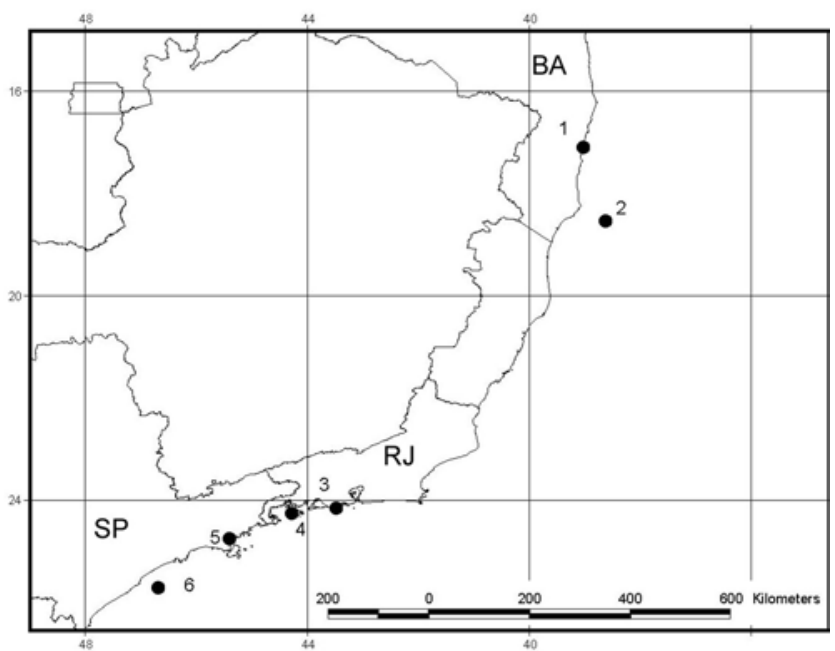

Figure 1. Localities along the Brazilian coast where samples of Mabuya spp. were collected for nematode surveys: (1) Trancoso, Bahia (BA), (2) Abrolhos archipelago, Bahia (BA), (3) Grumari, Rio de Janeiro (RJ), (4) Ilha Grande, Rio de Janeiro (RJ), (5) Caraguatatuba, São Paulo (SP), (6) Ilha da Queimada Grande, São Paulo (SP).

the skinks at each continental and insular site are shown in table II. The greatest number of species (four and three, respectively) were found in the continental localities of Grumari and Trancoso. Mean overall nematode richness was greatest for $M$. agilis from Grumari (1.05) and for M. macrorhyncha from Queimada Grande island (0.95), whereas the mean nematode richness of infected hosts was greatest for M. macrorhyncha from Trancoso and M. agilis from the Abrolhos archipelago (1.40 in both cases). Overall infection prevalences were very high ( > 80\%) for M. agilis from Grumari and M. macrorhyncha from Queimada Grande, in both cases due to the high prevalence of a particular nematode species (P. sceleratus in the former case and larval acuariids in the latter). The lowest infection rates were presented by $M$. caissara from Caraguatatuba (overall prevalence $=6.7 \%$ ) and by $M$. agilis from Ilha Grande (overall prevalence $=10.5 \%$ ). There seemed to be no clear pattern of association of insularity with the richness of infracommunities or component communities of Mabuya populations.

Mean overall nematode richness differed significantly among host populations (ANOVA: $\mathrm{F}_{6,131}=17.89 ; \mathrm{p}<0.001$ ). The two populations with the lowest values (Ilha Grande and Caraguatatuba) differed significantly from all others $(p<0.05)$ except among themselves and from M. macrorhyncha of Grumari. This latter population differed significantly $(\mathrm{p}<0.005)$ from Queimada Grande and from M. agilis of Grumari.

\section{DISCUSSION}

The present data did not evidence a tendency for insular Mabuya populations to have neither poorer nematode faunas nor lower infection prevalences than mainland ones or vice versa. Indeed, the insular population presenting the lowest infection rates (M. agilis from Ilha Grande) was that located 
Table I. Prevalence (in \%) of each nematode species on each Mabuya population surveyed. Sample sizes for each host population are given in parentheses. Insular populations of hosts are identified by the letter "I". Nematode species present only in larval stages are identified by an asterisk.

\begin{tabular}{|c|c|c|c|c|c|c|c|}
\hline \multirow[b]{2}{*}{ Nematodes } & \multirow{2}{*}{$\begin{array}{c}\text { Q. Grande (I) } \\
\begin{array}{c}\text { M. macrorhyncha } \\
(\mathrm{n}=19)\end{array}\end{array}$} & \multirow{2}{*}{$\begin{array}{c}\text { Caraguatatuba } \\
\begin{array}{c}\text { M. caissara } \\
(\mathrm{n}=30)\end{array}\end{array}$} & \multirow{2}{*}{$\begin{array}{c}\text { Ilha Grande (I) } \\
\begin{array}{c}\text { M. agilis } \\
(\mathrm{n}=19)\end{array}\end{array}$} & \multicolumn{2}{|r|}{ Grumari } & \multirow{2}{*}{$\begin{array}{c}\text { Abrolhos }(\mathrm{I}) \\
\begin{array}{c}\text { M. agilis } \\
(\mathrm{n}=11)\end{array}\end{array}$} & \multirow{2}{*}{$\begin{array}{c}\text { Trancoso } \\
\begin{array}{c}\text { M. macrorhyncha } \\
(\mathrm{n}=9)\end{array}\end{array}$} \\
\hline & & & & $\begin{array}{l}\text { M. agilis } \\
(\mathrm{n}=42)\end{array}$ & $\begin{array}{l}\text { M. macrorhyncha } \\
(\mathrm{n}=9)\end{array}$ & & \\
\hline Hexametra boddaertii* & - & - & - & - & - & - & 11.1 \\
\hline Parapharyngodon largitor & - & - & - & 2.4 & - & - & - \\
\hline Parapharyngodon sceleratus & 10.5 & 3.3 & - & 88.1 & 22.2 & 36.4 & 55.6 \\
\hline Physaloptera sp.* & - & - & 5.3 & 2.4 & - & 27.3 & - \\
\hline Physalopteroides venancioi & - & - & - & - & - & - & 11.1 \\
\hline Acuariidae indet.* & 84.2 & 3.3 & 5.3 & 9.5 & - & - & - \\
\hline
\end{tabular}

Table II. Total nematode richness (TR), mean nematode richness per host (MRH), mean nematode richness per infected host (MRIH, with maximum value in parenthesis), and total nematode prevalence (in absolute numbers and in proportions) for different host populations of species of the genus Mabuya living on islands and on adjacent mainland areas along the coast of the Brazilian states of São Paulo, Rio de Janeiro and Bahia. Sample sizes are given in parentheses for each species in each locality. Values for MRH and MRIH are given as arithmetic means plus one standard deviation.

\begin{tabular}{|c|c|c|c|c|c|c|c|c|c|}
\hline \multirow{2}{*}{ Host } & \multicolumn{4}{|c|}{ Islands } & \multirow{2}{*}{ Host } & \multicolumn{4}{|c|}{ Mainland adjacent areas } \\
\hline & TR & $\mathrm{MRH}$ & MRIH & Prevalence (\%) & & $\mathrm{TR}$ & $\mathrm{MRH}$ & MRIH & Prevalence (\%) \\
\hline $\begin{array}{l}\text { Queimada Grande, SP } \\
\text { M. macrorhyncha (19) }\end{array}$ & 2 & $0.95 \pm 0.52$ & $1.13 \pm 0.34(2)$ & $16(84.2 \%)$ & $\begin{array}{c}\text { Caraguatatuba, SP } \\
\text { M. caissara }(30)\end{array}$ & 2 & $0.07 \pm 0.25$ & $1(1)$ & $2(6.7 \%)$ \\
\hline $\begin{array}{c}\text { Ilha Grande, RJ } \\
\text { M. agilis (19) }\end{array}$ & 2 & $0.10 \pm 0.32$ & $1(1)$ & $2(10.5 \%)$ & $\begin{array}{l}\text { Grumari, RJ } \\
\text { M. agilis (42) }\end{array}$ & 4 & $1.05 \pm 0.49$ & $1.16 \pm 0.37(2)$ & $38(90.5 \%)$ \\
\hline & & & & & M. macrorhyncha (9) & 1 & $0.22 \pm 0.44$ & $1(1)$ & $2(22.2 \%)$ \\
\hline $\begin{array}{l}\text { Abrolhos, BA } \\
\text { M. agilis (11) }\end{array}$ & 2 & $0.64 \pm 0.81$ & $1.40 \pm 0.55(2)$ & $5(45.4 \%)$ & $\begin{array}{l}\text { Trancoso, BA } \\
\text { M. macrorhyncha (9) }\end{array}$ & 3 & $0.78 \pm 0.83$ & $1.40 \pm 0.55(2)$ & $5(55.6 \%)$ \\
\hline
\end{tabular}

closest to the mainland. The highest rates of infection were found for M. agilis from Grumari (a mainland locality) and for M. macrorhyncha from Queimada Grande (an insular locality). Likewise, the two populations with the lowest infection rates were a continental (M. caissara from Caraguatatuba) and an insular one ( $M$. agilis from Ilha Grande). Those two populations also presented the lowest mean overall nematode richness. When only infected individuals were considered, however, there was a general tendency for a single nematode species per host in all populations, with the two samples from Bahia state presenting only a slight tendency for richer infracommunities. This indicates that nematode infracommunities of coastal Brazilian Mabuya tend to be generally depauperate, independent of the degree of isolation from other Mabuya populations.

Other Mabuya populations from coastal restingas have shown a tendency for somewhat richer nematode infracommunities than the ones studied here. Populations of $M$. agilis from the restingas of Praia das Neves, in Espírito Santo state, and Grussaí, in Rio de Janeiro state were host to, respectively, four and five nematode species (VRCibradic et al. 2002b) and the overall mean nematode richness per host was 2.09 (n $=11)$ and $1.89(\mathrm{n}=28)$, respectively (D. VRCIBRADIC, unpublished data). In another restinga of Rio de Janeiro state
(Jurubatiba), the local population of $M$. agilis had an overall mean nematode richness per host of $1.86(\mathrm{n}=8)$ (VRCIBRADIC et al. 2000). This indicates that nematode infection parameters may differ more among different continental populations of Mabuya than between continental and insular populations.

The total nematode species pool available to infect lizards of the genus Mabuya along the eastern Brazilian coast appears to be limited. In fact, the six nematode species recorded in the present study represent the near totality of the nematode species so far recorded for Mabuya spp. populations surveyed along the Brazilian coast, with only Strongyluris oscari Travassos, 1923 missing (van SluYs et al. 1997, Ribas et al. 1998b, VRCIBRADIC et al. 2000, 2001, 2002a,b). However, the nematode communities of most of the Mabuya populations here studied comprised no more than two species, indicating a local variation in the occurrence of particular nematode species. All of the insular populations studied here had a total nematode richness of two, which may suggest an impoverishment of the nematode species pool on islands. Indeed, although the continental populations did not generally show visibly higher richness values than the insular ones (the value of four for the $M$. agilis population of Grumari is somewhat misleading, since this is the host population represented by the largest sample size and two of the nematodes occurred in a single host indi- 
vidual each), there are the already mentioned cases of coastal mainland Mabuya populations presenting up to five nematode species. However, when such richness values are adjusted for host sample size (i.e. as number of nematode species per infected host), both insular and mainland populations tend toward a single nematode species per host individual, as previously mentioned.

In their study on helminth faunas of lesser antillean Anolis lizards, Dobson et al. (1992) did not find an association of parasite richness or burdens with island area or distance from a potential colonizing source (Puerto Rico), but found instead that habitat type (mesic vs. xeric) had some influence on parasite richness and infection rates of host populations. Likewise, island area and distance from the mainland appear unimportant with regard to parasite burdens of Mabuya populations in the present study. Among the three insular sites surveyed, Ilha Grande had the host population with the lowest infection rates, in spite of that island being only $1.5 \mathrm{~km}$ away from the mainland (compared to $33 \mathrm{~km}$ for Queimada Grande and ca. $70 \mathrm{~km}$ for the Abrolhos archipelago) and of its proximity to an area (Grumari) where a conspecific host population occurs with high infection rates. Also, Ilha Grande is several times the size of the other two islands. Conversely, the highest infection rates were found in the host population from Queimada Grande, which is intermediate between the other two in both area and distance from the nearest coast, but also represents a more mesic environment. Thus, the results presented here seem to agree in such respects with those of Dовson et al. (1992). But it should be considered here that the high infection rates presented by the Queimada Grande host population were due to the occurrence of acuariid larvae, which do not complete their life cycle in reptilian hosts and probably represent paratenic or accidental parasitism in lizards (see VRCibRadic et al. 2000).

Present data show that, although there may be a trend for insular Mabuya populations to have an impoverished nematode fauna relative to mainland ones, this is obscured by the fact that nematode assemblages of such lizards in coastal Brazil tend to be generally poor overall. Other similar works on different host species/genera are desirable to verify if such a trend really exists.

\section{ACKNOWLEDGEMENTS}

This study is portion of the results of the "Programa de Ecologia, Conservação e Manejo de Ecossistemas do Sudeste Brasileiro" and of the Southeastern Brazilian Vertebrate Ecology Project (Vertebrate Ecology Laboratory), both of the Setor de Ecologia, Instituto de Biologia, Universidade do Estado do Rio de Janeiro. We thank the field assistantship of many colleagues during collection of the lizards. Charles R. Bursey and Joaquim J. Vicente helped with the identification of some of the nematodes. This study was partially supported by a research grant from the Fundação de Amparo à Pesquisa do Estado do Rio de Janeiro - FAPERJ (process E-26/170.385/97 - APQ1) and by fellowships from the Conselho Nacional de Desenvolvimento Científico e Tecnológico - CNPq to CFDR (processes 300819/94-3 and 477981/03-8) and to DV (process 143607/987). We also thank the Instituto Brasileiro do Meio Ambiente e Recursos Naturais Renováveis - IBAMA for providing us the collection permit \# 137/99 (process 02001.000710/97-89).

\section{REFERENCES}

Ано, J.M. 1990. Helminth communities of amphibians and reptiles: comparative approaches to understanding patterns and processes, p. 157-195. In: G.W. Esch; A.O. Bush \& J.M. Ано (Eds). Parasite communities: patterns and processes. New York, Chapman \& Hall, 304p.

Biserkov, V. \& A. Kostadinova. 1998. Intestinal helminth communities of the green lizard Lacerta viridis from Bulgaria. Journal of Helmithology, Wallingford, 72: 267-271.

Bush, A.O.; J.M. Ано \& C.R. Kennedy. 1990. Ecological versus phylogenetic determinants of helminth parasite community richness. Evolutionary Ecology, Dodrecht, 4: 1-20.

Bush, A.O.; K.D. Lafferty; J.M. Lotz \& A.W. Shostak. 1997. Parasitology meets ecology in its own terms: Margolis et al. revisited. Journal of Parasitology, Washington, D.C., 83 (4): 575-583.

Dobson, A.P. \& S.W. PACALa. 1992. The parasites of Anolis lizards in the northern Lesser Antilles II. The structure of the parasite community. Oecologia, Berlin, 91: 118-125.

Dobson, A.P.; S.V. Pacala; J.D. Roughgarden; E.R. Carper \& E.A. Harris. 1992. The parasites of Anolis lizards in the northern Lesser Antilles I. Patterns of distribution and abundance. Oecologia, Berlin, 91: 110-117.

MacArthur, R.H.; E.O. Wilson. 1963. An equilibrium theory of insular zoogeography. Evolution, Lawrence, 17: 373-387.

. 1967. Island Biogeography. Princeton, Princeton University Press, 203p.

Poulin, R. \& S. Morand. 2000. The diversity of parasites. Quarterly Review of Biology, Chicago, 75 (3): 277-293.

RebouÇAS-SPIEkER, R. 1974. Distribution and differentiation of animals along the coast and in continental islands of the state of São Paulo, Brazil. 2. Lizards of the genus Mabuya (Sauria, Scincidae). Papéis Avulsos de Zoologia, São Paulo, 28 (12): 197-240.

Ribas, S.C.; C.F.D. Rocha; P.F. Teixeira Filho \& J.J. Vicente. 1995. Helminths (nematoda) of the lizard Cnemidophorus ocellifer (Sauria: Teiidae): assessing the effect of rainfall, body size and sex in the nematode infection rates. Ciência e Cultura, São Paulo, 47: 88-91.

Ribas, S.C.; C.F.D. Rocha; P.F. Teixeira Filho \& J. J. Vicente. 1998 a. Nematode infection in two sympatric lizards (Tropidurus torquatus and Ameiva ameiva) with different foraging tactics. Amphibia-Reptilia, Leiden, 19: 323-330.

Ribas, S.C.; P.F. Teixeira Filho; C.F.D. Rocha \& J. J. Vicente. 1998 b. Parasitismo por nematódeos em duas espécies simpátricas de Mabuya (Lacertilia: Scincidae) na restinga da Barra de Maricá, RJ. Anais do VIII Seminário Regional de Ecologia de São Carlos 2, p. 883-894.

Rocha, C.F.D. 1995. Nematode parasites of the Brazilian sand lizard (Liolaemus lutzae). Amphibia-Reptilia, Leiden, 16: 412-415.

- 2000. Biogeografia de Répteis de Restinga: Distribuição, ocorrências e endemismos, p. 99-116. In: F.A. EsTEVES \& L.D. LACERDA (Eds). Ecologia de restingas e lagoas costeiras. Macaé, NUPEM/UFRJ, 394p.

Rocha, C.F.D.; D. VRcibradic; J.J. Vicente; M.Cunha-Barros. 2003. Helminths infecting Mabuya dorsivittata (Lacertilia, scincidae) from a high-altitude habitat in Itatiaia National Park, 
Rio de Janeiro State, southeastern Brazil. Brazilian Journal of Biology, Rio de Janeiro, 63 (1): 129-132.

Rozenzweig, M.L. 1995. Species diversity in space and time. Cambridge, Cambridge University Press, 436p.

Sharpilo, V.P.; V. Biserkov; A.Kostadinova; J.M. Behnke \& Y.I. KuzMin. 2001. Helminths of the sand lizard, Lacerta agilis (Reptilia, Lacertidae), in the Palaearctic: faunal diversity and spatial patterns of variation in the composition and structure of component communities. Parasitology, Cambridge, 123: 389-400.

van Sluys, M.; C.F.D. Rocha \& S.C. Ribas. 1994. Nematodes infecting the lizard Tropidurus itambere in southeastern Brazil. Amphibia-Reptilia, Leiden, 15: 405-408.

van Sluys, M.; C.F.D. Rocha; H.G. Bergallo; D. Vrcibradic \& S.C. RiBAs. 1997. Nematode infection in three sympatric lizards in an isolated fragment of restinga habitat in Southeastern Brazil. Amphibia-Reptilia, Leiden, 18: 442-446.

Vrcibradic, D.; C.F.D. Rocha \& S.C. Ribas. 1999. Nematodes infecting the skink Mabuya frenata in an area of rock outcrops in Southeastern Brazil. Amphibia-Reptilia, Leiden, 20: 333-339.

Vrcibradic, D.; M.Cunha-Barros; J.J. Vicente; C.A.B. Galdino; F.H. Hatano; M. Van Sluys \& C.F.D. Rocha. 2000. Nematode infection patterns in four sympatric lizards from a restinga habitat (Jurubatiba) in Rio de Janeiro State, southeastern Brazil. Amphibia-Reptilia, Leiden, 21: 307-316.

Vrcibradic, D.; C.F.D. Rocha; M. Van Sluys \& C.R. Bursey. 2001. Natural history notes. Mabuya macrorhyncha. Endoparasites. Herpetological Review, Cincinnati, 32 (4): 256-257.

VRcibradic, D.; C.F.D. Rocha; C.R. Bursey \& J.J. Vicente. 2002a. Helminths infecting Mabuya agilis (Lacertilia, Scincidae) in a restinga habitat (Grumari) of Rio de Janeiro, Brazil. Amphibia-Reptilia, Leiden, 23: 109-114.

2002b. Helminth communities of two sympatric skinks (Mabuya agilis and Mabuya macrorhyncha) from two "restinga" habitats in southeastern Brazil. Journal of Helmithology, Wallingford, 76: 355-361.

Received in 27.VI.2003; accepted in 18.XI.2003. 